УДК: 658.7:656.2

\title{
МАРКЕТИНГОВО-ЛОГІСТИЧНИЙ ПІДХІД ЩОДО РОЗВИТКУ ТРАНСПОРТНО-ЛОГІСТИЧНОЇ ІНФРАСТРУКТУРИ ПІДПРИСМСТВ ЗАЛІЗНИЧНОГО ТРАНСПОРТУ
}

\author{
Дикань В.Л., д.е.н., професор, \\ Кузьменко А.В., аспірант (УкрДУЗТ)
}

В статті обтрунтована необхіність розвитку транспортно-логістичної інфраструктури підприємств залізничного транспорту за рахунок застосування маркетингологістичного підходу. Досліджено особливості формування та використання маркетингологістичного підходу в транспортній сфері. Визначені та детально окреслені принципи маркетинго-логістичного підходу. Сформована узагальнена схема маркетингово-логістичного підходу до розвитку транспортно-логістичної інфраструктури підприємств залізничного транспорту.

Ключові слова: маркетинг, логістика, маркетингово-логістичний підхід, транспортно-логістична інфраструктура, залізничний транспорт

\section{МАРКЕТИНГОВО-ЛОГИСТИЧЕСКИЙ ПОДХОД К РАЗВИТИЮ ТРАНСПОРТНО-ЛОГИСТИЧЕСКОЙ ИНФРАСТРУКТУРЫ ПРЕДПРИЯТИЙ ЖЕЛЕЗНОДОРОЖНОГО ТРАНСПОРТА}

\author{
Дикань В.Л., д.э.н., профессор, \\ Кузьменко А.В., аспирант (УкрГУЖТ)
}

B статье обоснована необходимость развития транспортно-логистической инфраструктуры предприятий железнодорожного транспорта за счет применения маркетинго-логистического подхода. Исследованы особенности формирования и использования маркетинго-логистического подхода в транспортной сфере. Определень и подробно раскрыты принципы маркетинго-логистического подхода. Составлено обобщенную схему маркетингово-логистического подхода к развитию транспортно-логистической инфраструктуры предприятий железнодорожного транспорта.

Ключевые слова: маркетинг, логистика, маркетингово-логистический подход, транспортно-логистическая инфраструктура, жселезнодорожный транспорт.

\section{MARKETING AND LOGISTICS APPROACH TO TRANSPORT AND LOGISTICS INFRASTRUCTURE OF RAILWAY TRANSPORT ENTERPRISES}

\author{
Dykan V.L., Doctor of Economics, Professor, \\ Kuzmenko A.V., graduate student (USU of RT)
}

The development of transport and logistics infrastructure in the railway sector enterprises Ukraine, as noted earlier, is a matter of national importance, the resolution of which will affect the overall socio-economic situation in the country and provide quality improving performance of railway undertakings. Today transport existing facilities and logistics infrastructure of railway undertakings not allow for integrated transport and logistics services, and, accordingly, the process of transport and logistics service takes place in the absence of complete unity technological organizations and all participants of the transport process. 
The article substantiates the need for the development of transport and logistics infrastructure of railway transport through the use of marketing and logistics approach. The features of the formation and use of marketing and logistical approach in the transport sector. Determined and disclosed in detail the principles of marketing and logistics approach. Compiled generalized scheme of marketing and logistical approach to the development of transport and logistics infrastructure of railway transport.

Keywords: marketing, logistics, marketing and logistical approach, the transport and logistics infrastructure, railway transport.

Постановка проблеми. Розширення процесів глобалізації та створення інформаційно-комунікаційних технологій звели нанівець діючі до цього класичні методи конкурентної боротьби та обумовили якісні трансформації моделей поведінки споживачів. В сьогочасних конкурентоспроможність умовах підприємства як і його розвиток багато в чому залежить не тільки від володіння інформацією про ринок і його споживачів, вміння адекватно та своєчасно реагувати на всі ринкові перетворення, але й базується на здатності залучати клієнтів в процес створення додаткової цінності пропозиції. Як відзначають Дж. Шет та К. Услей концепція спільного створення цінності поступово заміняе парадигму обміну в маркетингу та поширюється на діяльність багатьох компаній й ринків [1], а успіх компаній в значній мірі залежить від їх здатності залучати в процес спільного виробництва своїх клієнтів [2].

3 посиленням конкуренції кардинально змінилася і роль транспортного комплексу. Сьогодні послуги з транспортування вантажів $\epsilon$ чи не найбільш вагомими в організації процесу постачання товарів, адже пов'язані не лише суто 3 процесом транспортування продукції від виробника до споживача, а й включають велику кількість експедиторських та інформаційних операцій, послуги 3 термінальної обробки вантажів, їх складування, страхування, охорону та інші послуги, що реалізують на різних об'єктах транспортнологістичної інфраструктури (ТЛІ). Фактично рівень транспортно-логістичного обслуговування сприймається на рівні з такими атрибутами товару, як ціна, дизайн, технічні характеристики та якість, а об’єкти ТЛІ розглядають важливою ланкою процесу доведення продукції до споживача.

Досвід європейських країн свідчить, що розвиток ї ТЛІ орієнтовано на задоволення потреб вантажовласників (промисловості, торгівлі, сільського господарства), виходячи 3 номенклатури вантажів (товарів, продукції), їх кількості та вартості, місця розташування i призначення, та грунтується на забезпеченні гнучкої адаптації до вимог ринку і необхідності надання транспортних послуг у встановлені терміни (потрібний товар в потрібному місці, в потрібний час 3 мінімальними витратами). За своїм функціональним призначенням такі інфраструктурні об'єкти виконують окрім стандартних операцій 3 управління вантажорухом, ще й функції аналізу споживачів, координації попиту і пропозиції на ринку перевезень, забезпечують оптимальне співвідношення інтересів всіх учасників транспортного процесу та ефективну взаємодію різних видів транспорту. В свою чергу ефективність функціонування будь-якого об'єкту ТЛІ залежить від розробленої схеми доставки вантажу, термінів та якості виконання замовлення, а також враховує рівень задоволеності вантажовласника наданими транспортно-логістичними послугами. Все це вказуе на необхідність врахування при розбудові ТЛІ поряд з логістичною складовою організації їх діяльності ще маркетингової, що дозволяс з'ясувати потреби різних груп споживачів та створити умови для їх максимального задоволення.

Аналіз останніх досліджень $i$ публікацій. Питання розвитку транспортнологістичної інфраструктури знайшли відображення в працях багатьох вітчизняних та закордонних вчених. Серед них особливим напрацюванням відзначають наукові розробки I. Аксьонова, О. Дейнеки, Ю. Задворного, В. Копитка, Г. Озерської та інших [3-8]. Разом 3 цим, потребують подальшого висвітлення проблеми розвитку ТЛІ підприємств залізничного транспорту (ТЛІ ПЗТ), які б враховували особливості взаємодії маркетингової й логістичної складових в процесах їх розвитку. 
3 огляду на актуальність розвитку об'єктів ТЛІ ПЗТ та необхідність забезпечення відповідності рівня якості їх послуг 3 міжнародним стандартом транспортнологістичного обслуговування метою сmammi $\epsilon$ обгрунтування доцільності застосування та розкриття змісту маркетингово-логістичного підходу щодо розвитку ТЛІ підприємств залізничної галузі, як інтегрованого інструментарію дій щодо досягнення змін в сфері транспортно-логістичної діяльності підприємств Укрзалізниці.

\section{Виклад основного}

дослідження. В економічні літературі взаємозв'язок маркетингової i логістичної складових знайшов своє втілення в існуванні специфічного підходу - маркетинговологістичного. Його концепція при дослідженні розвитку транспортної інфраструктури грунтується на показнику «мобільності», що дозволяє оцінити ефективність реагування на потреби в транспортних послугах та гнучко адаптуватися до змін і вимог соціальноекономічного середовища для своєчасного, якісного i максимально ефективного задоволення потреб населення i народного господарства в транспортних послугах $[9$, с. 20].

Маркетингово-логістичний підхід $\epsilon$ синтезом маркетингового та логістичного підходів, що обумовлює необхідність вивчення особливостей кожного 3 них окремо. Дослідження літературних джерел дозволило встановити, що маркетинговий підхід [10]:

1) зорієнтований на максимальне задоволення потреб споживачів шляхом, 3 одного боку, всебічного дослідження ринку, вивчення попиту споживачів (їх вподобань і потреб), а 3 іншого - за рахунок формування потреб та бажань споживачів, визначення майбутніх ринкових потреб;

2) реалізується на основі впровадження комплексу маркетингових засобів та інструментів, що відображені в концепції «7Р» та включають такі групи, як товар, ціна, місце, просування, корпоративна філософія, бізнеспроцеси і персонал;

3) грунтується на правильному позиціюванні та успішному впровадженні товару (послуги) на ринок, а також створенні ефективної бізнес-моделі та формуванні сегменту лояльних споживачів.
Особливістю транспортного комплексу $\epsilon$ те, що споживачі транспортних послуг не мають можливості попередньо здійснити оцінку якості транспортної послуги, а керуються, головним чином, наданою інформацією про імідж компанії та можливий рівень сервісу. Лише порівнюючи реальний рівень транспортного обслуговування 3 очікуваним чи обіцяним, споживач має можливість оцінити діяльність даного транспортного підприємства [11].

Відповідно до цього, можна говорити про те, що маркетинговий підхід в сфері транспортного обслуговування передбачає виявлення та формування специфічних потреб клієнтів - споживачів транспортних послуг i потреб в комплексному обслуговуванні, що включає як безпосереднє виконання перевезень, так і послуги 3 переробки вантажів, ix складування та митне оформлення, інформаційне супроводження вантажопотоків. Це можливо реалізувати шляхом [12]:

по-перше, постійного моніторингу i прогнозування кон'юнктури транспортного ринку;

по-друге, вивчення можливостей якісного задоволення попиту на перевезення за рахунок новітніх транспортних технологій та інфраструктури;

по-трете, забезпечення якості, інформативності та цінової диференціації послуг $з$ транспортного обслуговування.

На відмінну від маркетингового логістичний підхід ототожнюється з системним підходом та реалізується через такі принципові положення [13; 14]:

$$
\text { - взаємопов'язані }
$$

функції

розглядаються як єдиний потік;

- для управління потоком створюється відповідна система (організаційноуправлінський механізм). В рамках таких систем, по-перше, сумарний ефект від оптимізації потоку може значно перевищувати прибуток від локальної оптимізації окремих його функцій та операцій; по-друге, здійснюється перерозподіл витрат, при якому їх збільшення в одній ділянці дає економію в іншій та по системі в цілому;

$$
\text { - оцінювання }
$$

ефективності функціонування системи управління потоком здійснюється з урахуванням не тільки витрат, а ще й втрат прибутку, зумовлених 
нераціональним використанням ресурсів потоку.

Логістичний підхід до організації бізнесу орієнтований на розвиток постачань споживачам товарів на принципах «точно в термін», «від дверей до дверей» на основі використання наскрізних транспортнологістичних технологій вода-повітря-земля та додаткових сервісних: різні види зберігання, крос-докінг та інше [15]. Сукупний ефект його використання проявляється в формуванні логістичних систем та ланцюгів, які забезпечують [16]:

- орієнтацію виробництва на потреби ринку. Створюється можливість для ефективного переходу від малосерійного до індивідуального виробництва;

- налагодження

партнерських

взаємозв'язків;

- скорочення простоїв обладнання за рахунок наявності необхідних матеріалів для виробництва;

- зменшення чисельності допоміжних робітників;

- підвищення якості продукції;

- зниження рівня втрат матеріалів;

- покращення використання

виробничих та складських площ.

Отже, погоджуючись 3 думкою більшості науковців маркетинговий та логістичний підходи необхідно розглядати як взаємопов'язані концепції розвитку бізнесу, що забезпечують орієнтацію цілей розвитку на створення цінностей для споживачів та реалізацію синергетичного ефекту.

Розвиток ТЛІ на підприємствах залізничної галузі Україні, як відзначалося раніше, $є$ питанням загальнодержавного значення, вирішення якого вплине на загальну соціально-економічну ситуацію в країні та забезпечить якісне покращення показників діяльності підприємств Укрзалізниці. Сьогодні існуючі об'єкти ТЛІ підприємств Укрзалізниці не дозволяють забезпечити комплексність транспортно-логістичної послуги, a, відповідно, сам процес транспортнологістичного обслуговування протікає за умови відсутності повної технологічної та організаційної єдності всіх учасників транспортного процесу. Рівень обслуговування та якість транспортно-логістичних послуг в даних об'єктах ТЛІ не відповідають основним вимогам вантажовідправників та стандартам міжнародного транспортно-логістичного обслуговування, а відповідно негативно впливають на імідж підприємств залізничного транспорту та обумовлюють зниження лояльних споживачів.

Адже в умовах розвитку транспортнологістичного ринку та існування величезної кількості суб'єктів транспортно-логістичної діяльності для сучасного споживача вже не достатньо лише просто забезпечити доставку вантажу в місце призначення. Вагомий вплив на формування споживчого попиту на транспортно-логістичні послуги здійснює також і надійність та своєчасність перевезень, імідж компанії та доступність обслуговування нею, діюча система тарифів, існуючий портфель транспортних послуг (можливість отримання послуги в одній особі), інформативність та технологічна взаємодія 3 іншими видами транспорту.

Відповідно до цього, на думку авторів статті, розвиток ТЛІ ПЗТ має відбуватися на основі комплексного вивчення вимог та запитів споживачів, постійного моніторингу змін на ринку транспортно-логістичних послуг, а також передбачати розширення портфелю послуг, формування раціональної тарифної політики, вибір оптимального місця їх територіального розміщення та впровадження ефективної системи планування перевезень.

Тому маркетингово-логістичний підхід до розвитку ТЛІ ПЗТ повинен враховувати параметри транспортно-логістичного обслуговування підприємствами залізничної галузі, інструменти просування послуг та завоювання лояльності їх споживачів. При цьому маркетингова складова даного підходу реалізується у взаємозв'язку між параметрами та структурою об'єктів ТЛІ ПЗТ, забезпеченні їх відповідністі вимогам та запитам споживачів транспортно-логістичних послуг, а логістична - в скоординованому формуванні об'єктів ТЛІ та реалізації логістичних технологій обслуговування. Узагальнена схема авторського розуміння маркетинговологістичного підходу до розвитку ТЛІ підприємств Укрзалізниці подана на рисунку 1. 


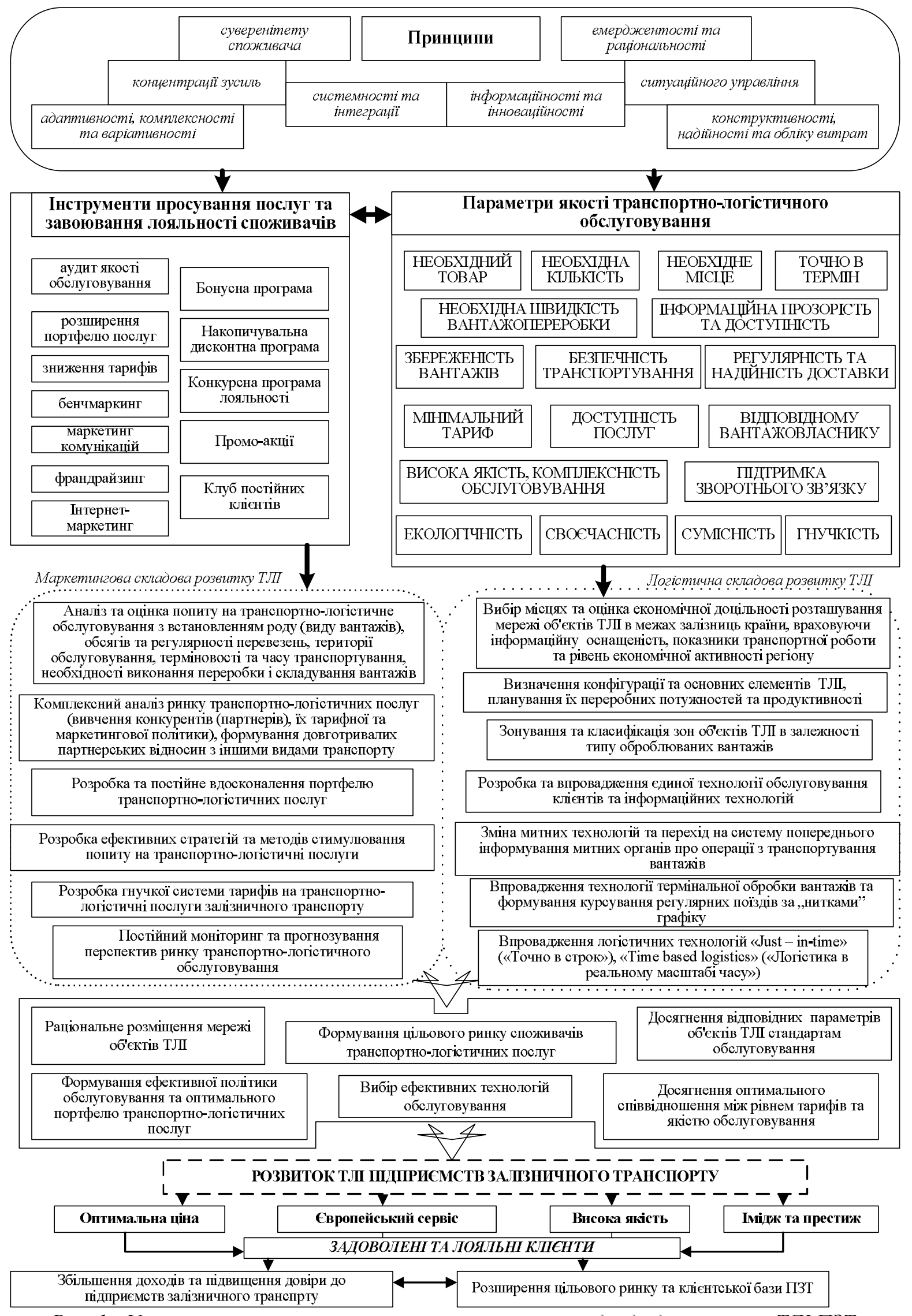

Рис. 1.- Узагальнена схема маркетингово-логістичного підходу до розвитку ТЛІ ПЗТ

Вісник економіки транспорту і промисловості № 51, 2015 
В основу даного підходу запропоновано покласти такі маркетингові й логістичні принципи $[17,18]$ :

- суверенітету споживача - в його основу покладено розуміння того, що розвиток ТЛІ ПЗТ має відбуватися на основі постійного вивчення запитів та вимог споживачів, 3'ясування їх потреби в функціональному призначенні об'єктів ТЛІ;

- концентрації зусиль - передбачає концентрацію всіх ресурсів підприємств залізничної галузі над створенням ефективних об'єктів ТЛІ, що забезпечать вдосконалення роботи підприємств залізничного транспорту;

- ситуаційного управління - означає постійний моніторинг ситуації на ринку транспортно-логістичних послуг і формування на цій основі обгрунтованих рішень щодо подальших напрямків розвитку об'єктів ТЛІ, заснованих на ринкових прогнозах;

- комплексності - проявляється у всесторонньому прогресивному розвитку елементів ТЛІ у взаємозв'язку із зовнішніми суб'єктами;

- конструктивності - передбачає створення в об'єктах ТЛІ атмосфери співробітництва та довіри;

- надійності - означає зведення до мінімуму можливості не виконання зобов'язань 3 транспортно-логістичного обслуговування об'єктами ТЛІ та можливості пошкодження (псування) вантажів;

- емерджентності - передбачає, що за рахунок розвитку на ПЗТ об'єктів ТЛІ можливо досягнути якісних змін в параметрах транспортно-логістичного обслуговування та забезпечити покращення економічного становища підприємств галузі;

- раціональності - грунтується на тому, що розвиток ТЛІ має відбуватися 3 врахуванням економічної активності регіонів, а саме вантажонапруженості ПЗТ i наявності крупних промислових зон, проходження міжнародних транспортних коридорів і транспортних магістралей;

- інформаційності - означає, що розвиток ТЛІ має відбуватися в умовах наявності достовірної інформації про стан ситуації на ринку транспортно-логістичних послуг та одночасно забезпечувати формування єдиного інформаційного простору в залізничній галузі;
- інноваційності інноваційний характер транспортно-логістичної підприємств залізничного транспорту;

- системності та інтеграції - означає, що об'єкти транспортно-логістичної інфраструктури, 3 одного боку, знаходяться у взаємозв'язку між собою та виступають елементом єдиної системи транспортнологістичного обслуговування підприємств залізничного транспорту країни, що підсилює його перевізні спроможності.

Особливість даного підходу полягає в тому, що за рахунок інтеграції маркетингового i логістичного інструментарію розвитку буде забезпечено:

- раціональне розміщення мережі об'єктів ТЛІ ПЗТ, що реалізується шляхом визначення потенційного ринку споживачів транспортно-логістичних послуг та з'ясування кількості і місця розташування відповідних інфраструктурних об'єктів;

- формування цільового ринку споживачів транспортно-логістичних послуг;

- досягнення відповідності параметрів об'єктів ТЛІ стандартам транспортнологістичного обслуговування;

- формування ефективної політики обслуговування та оптимального портфелю транспортно-логістичних послуг;

- вибір ефективних технологій обслуговування вантажного потоку;

досягнення оптимального

співвідношення між рівнем тарифів та якістю транспортно-логістичного обслуговування.

В цілому реалізація маркетинговологістичного підходу до розвитку об'єктів ТЛІ ПЗТ сприятиме не тільки досягненню змін в структурі та параметрах об'єктів ТЛІ ПЗТ, але й забезпечить розширення клієнтської бази галузі та створення позитивного іміджу підприємств залізничної транспорту як найбільш надійного транспортно-логістичного оператора в країні.

Висновок. Отже, розвиток об'єктів ТЛІ ПЗТ як інтегрованого базового компоненту, який визначає швидкість та якість транспортно-логістичного обслуговування, має відбуватися 3 уврахуванням вимог споживачів та грунтуватись на використанні інтегрованого інструментарію розвитку. Маркетинговологістичний підхід щодо розвитку ТЛІ 
підприємств залізничної галузі враховує параметри транспортно-логістичного обслуговування підприємствами залізничної галузі, інструменти просування послуг та завоювання лояльності їх споживачів, а також передбачає за рахунок інтеграції маркетингового і логістичного інструментарію розвитку забезпечення ефективного розміщення об'єктів ТЛІ ПЗТ, та відповідності портфелю транспортно-логістичних послуг сучасним вимогам споживачів.

\section{СПИСОК ЛІТЕРАТУРИ}

1. Sheth J. N. Implications of the Revised Definition of Marketing: From Exchange to Value / J. N. Sheth, C. Uslay // Journal of Public Policy and Marketing. - 2007. - Vol. 26, № 2.- P. 302-307.

2. Prahalad C.K. The Future of Competition: Co-Creating Value with Customers / C.K. Prahalad, V. Ramaswamy. - Boston: Harvard Business Press, 2004. -P. 58-62

\section{3. Аксьонов I.M.}

економічного механізму пасажирським комплексом транспорту України: автореф. дис. на здобуття наук. ступеня докт. екон. наук; спеціальність: 08.00.03 «Економіка та управління національним господарством» / I.M. Аксьонов. - Харків, 2008. - 32 с.

4. Дейнека О.Г. Теоретичні та методологічні складові розвитку залізничного транспорту України / О.Г. Дейнека, Л.О. Позднякова // Вісник економіки транспорту і промисловості. - 2008. - № 25. - С. 62-65.

5. Сдина транспортна система: навчальний посібник [Текст] / [Соболєв Ю. В., Дикань В. Л., Дейнека О. Г., Писаревський І. М., Позднякова Л. О.]. - Харків: ООО «Олант», 2002. - 288 с.

6. Задворный Ю.В. Критерии оценки развития транспортной инфраструктуры региона / Ю.В. Задворный // Российское предпринимательство. - 2011. - № 1 (175). - С. $168-178$.

7. Копитко B.I. Тенденції розвитку сучасної інфраструктури залізничного транспорту, враховуючи маркетинговологістичний підхід [Електронний ресурс]./ B.I. Копитко - Режим доступу: http://www.ekuzt.gov.ua/node/22. - Назва 3 екрана.

8. Озерська Г.В. Розбудова мережі міжнародних транспортно-логістичних центрів в умовах інтеграції до світової транспортної системи / Г.В. Озерська // Наука й економіка. 2014. - № 4 (36). - С. 134 - 140.

9. Морозова И.А. Маркетинговое обеспечение развития инфраструктуры ринка транспортных услуг: автореф. дисс. на соиск. учен. степени д.э.н.; специальность: 08.00 .05 «Экономика и управление народным хояйством (3. Маркетинг)» / И.А. Морозова. - Волгоград, 2008. $-50 \mathrm{c}$.

10.Предводителева М.Д. Подходы к управлению качеством услуг: фокус на потребителе / М.Д. Предводителева, О.Н. Балаева // Менеджмент в России и за рубежом. 2005. - № 2. - C. 90-100.

11.Кузьменко А. В. Процес розробки маркетингової стратегії підприємства / А. В. Кузьменко // Вітчизняна наука: сучасний стан, актуальні проблеми та перспективи розвитку: матеріали I Всеукраїнська науково-практична інтернет - конференція (29 - 31 жовтня 2011 р., Переяслав-Хмельницький). - ПереяславХмельницький, 2011. - С. 73 - 75.

12. Кузьменко А. В. Поняття маркетингу та логістики в діяльності підприємств / А. В. Кузьменко // Актуальні питання організації та управління діяльністю підприємств у сучасних умовах господарювання: тези доповідей III науково-практичної конференції Академії внутрішніх військ МВС України (22 листопада 2013 р., Харків). - Харків, 2013. - С. 147 - 148.

13.Крикавський $€$. Логістичне управління: підручник / Є. Крикавський. Львів: Видавництво національного університету «Львівська політехніка», 2005. $684 \mathrm{c}$.

14.Окландер М.А. Логістика: підручник / М.А. Окландер. -К.: Центр учбової літератури, 2008. - $346 \mathrm{c}$.

15.Кузьменко А. В. Сутність маркетингу та логістики в діяльності підприємств/ А. В. Кузьменко // Вісник економіки транспорту і промисловості. - 2013. — № 43. - С. 203-209.

16.Бартош А.А. Логистический подход в организации транспортного обслуживания / А.А. Бартош, Л.С. Хомич // Материалы III Республиканского научно-практического семинара молодых ученых «Проблемы и перспективы современной науки» (23 ноября 2012 г., г. Минск). - Минский институт управления, 2012. - С. 32-38. 
17.Кузьменко А. В. Основні принципи маркетинг-логістичного підходу на залізничному транспорті / А. В. Кузьменко // Проблемы экономики и управления на железнодорожном транспорте: IX Международная научно-практическая конференция (14 ноября - 14 декабря 2014 г.,
Киев). - Киев, 2014. - С. $309-310$.

18. Дикань В. Основи логістичної інтеграції при формуванні логістичних систем через утворення територіальнопромислового кластера / В. Дикань // Українські залізниці : міжнар. технікоекон. журн..- Харків 2014 - С. 22-26.

Експерт редакційної колегії к.е.н., доцент УкрДУЗТ Зубенко В.О.

УДК: 331.108:656.13

\title{
ОБГРУНТУВАННЯ МЕТОДУ ВИЗНАЧЕННЯ ТА ОЦІНКИ КОМПЕТЕНЦІЙ ПРАЦІВНИКІВ ПІДПРИЕМСТВА
}

\author{
Водолажська T.О., к.е.н., доцент (ХНАДУ)
}

Розглянуто існуючі методи визначення та оцінки компетенцій працівників підприємства, визначено основні їх переваги та недоліки. Встановлено критерії, за якими проведено порівняння існуючих методів. Обтрунтовано та проведено вибір найбільш доиільного методу визначення та оиінки компетенцій працівників - «Assessment center». Розроблено схему процесу їх визначення та уточнено зміст дій на кожному етапі.

Ключові слова: компетенції працівника, методи визначення компетенцій, оцінка компетенцій.

\section{ОБОСНОВАНИЕ МЕТОДА ОПРЕДЕЛЕНИЯ И ОЦЕНКИ КОМПЕТЕНЦИЙ РАБОТНИКОВ ПРЕДПРИЯТИЯ}

\section{Водолаэсская Т.А., к.э.н., доцент (ХНАДУ)}

\begin{abstract}
Рассмотрены существуюшие методы определения и оценки компетенций работников предприятия, определены основные их преимущества и недостатки. Выбраны критерии, по которым проведено сравнение существующих методов. Обоснован и проведен выбор наиболее иелесообразного метода определения и оиенки компетениий работников - «Assessment center». Разработана схема процесса их определения и уточнено содержание действий на каждом эmane.
\end{abstract}

Ключевые слова: компетенции работника, методы определения компетенций, оценка компетенций.

\section{JUSTIFICATION OF THE METHOD FOR DETERMINATION AND EVALUATION OF EMPLOYEES' COMPETENCIES}

\section{Vodolazhska T., Cand. Sc. (Econ.) (Kharkov National Automobile-Highway University)}

The article is devoted to the methods that can be applied for the identification and evaluation of employees' competencies. The criteria according to which the methods can be compared to each other were defined, they are: simplicity, minor material costs, accessibility, objectivity, and others. The selection process was justified and it was carried out in order to choose the most appropriate method 